\title{
2020 年度春季大会講演特集のご案内
}

2020 年度春季大会は，5月 26 日（火）～27日（水）に早稲田大学西早稲田キャンパス 63 号館において開催いたします。今大 会では 2 テーマの企画セッションと 4 テーマの講演特集を設けており，興味深い発表が予定されていますので，多くの方の参加 をお待ちしております。以下に今回の講演特集の特徵をご紹介します。また，プログラムにつきましては，会誌 4 月号，5月号 に掲載し，3月半ばには，Web 上で公開予定をしております.

\section{企画セッション}

\section{1. 粉末を出発原料とする材料・プロセスのシミュレーション技術}

粉末を出発原料とする材料合成技術では, 今後ますます精密かつ複雑なプロセス制御・設計が求められ，それに貢献するシ ミュレーション技術発展が期待されます。本分野におけるシミュレーション技術としては，粉末の合成，粉体の混合，粉末の成 形, 焼結のプロセス, 組織形成, 収縮・形状変化, 焼結体の加工等のシミュレーション技術などが考えられます。本セッション では, そのような粉体・粉末治金に関わるシミュレーション技術について，計算原理やシミュレーション解析，さらにはシミュ レーション適用等に関して, 最近の研究成果や技術動向に関する発表を特集し, 今後の研究課題等を議論します。モンテカルロ 法, 有限要素法, 離散要素法などの計算原理を用いた実用的, 実践的な研究成果が発表されます。奮ってご参加下さい.

\section{2. 環境・エネルギー材料最前線・2020}

新世紀と言われた 21 世紀が始まってはや 20 年. 東京オリンピック・パラリンピックが開催される 2020 年は,「地球温暖化」, 「ヒートアイランド」といった環境問題を，我々の生活に直結した問題として改めて認識させられる年となりました。我々の環 境問題への意識の高まりと相まって，「 $\mathrm{CO}_{2}$ 削減」「 $\mathrm{CO}_{2}$ 貯留」「環境モニタリング」「環境保全」「環境浄化」「エネルギー製造・ 輸送・貯蔵」「省エネルギー」「創エネルギー」「クリーンエネルギー」といった環境・エネルギー関連技術が大きく発展したの もこの 20 年間の動きと言えるでしょう。本セッションでは,「材料」の観点から, 環境問題，エネルギー問題の解決に取り組む 研究を幅広く取り上げ，活発な討論を行いたいと思います。粉体粉末冶金分野はもちろんのこと，環境・エネルギー関連分野の 多くの方々の積極的な参加を期待します.

\section{講演特集}

\section{1. 粉末治金技術と製品評価に関する新たな展開}

本特集では，粉末治金プロセスを用いた製造技術や製品および材料評価に関して幅広く議論することを目的としています。今 回は, 粉末圧密機構と焼結体組織解析に関する研究, 焼結合金や鉄系焼結材における高密度化および高ヤング率化や曲げ疲労強 度, 結晶組織制御と時効特性に関する研究, 種々の製造方法による各種熱電材料に関する研究, 各種材料のレーザ粉末積層造形 に関する研究, $\mathrm{Al}$ 系および $\mathrm{Cu}$ 系複合材料に関する研究, 積層構造の複合材料に関する研究など, 協会賞受賞記念講演 1 件, 特 別講演 2 件と招待講演 3 件を含む計 23 件の講演が予定されています．多くの方々にご参加頂き，活発な議論が交わされること を期待しております.

\section{2. 磁性材料・磁気デバイスにおける微細構造制御と機能発現}

本講演特集は, 今回も幅広く磁性材料・磁気デバイスに関する19件の講演で構成することができました。 ハード磁性，ソフ 卜磁性等の様々な磁気特性の材料やデバイス，またバルク，薄膜，微粒子等の形態を問わず，幅広く講演が集まりました，今回 も産官学からの応募件数もうまくバランスがとれ，多様な研究者が集う場になると期待されます。この特集のテーマである磁性 材料の構造制御は, その磁気特性を左右することから, 応用先である各種磁気デバイスの新機能・高機能発現にとって重要な技 術となっています。このような微細構造の創製・制御・評価技術のみならず，日本を代表する磁性技術に関係する幅広い研究開 発の発表の場となっているのは本特集の特徴であり，国内外でも例のないものと言えます．今後も世界をリードする磁気技術に 関する有益な議論の場になるよう多くの皆様の参加をお待ちしています。この講演特集をもとに新しい研究開発に向けて展開で きるような討論を実施したいと考えています．奮ってご参加ください.

\section{3. 金属射出成形の課題と更なる展開}

金属射出成形法（Metal Injection Molding, MIM）は, 1970 年代に米国で研究が開始されてから半世紀を迎えようとしています. この間に国内では各社・各研究機関の特色を活かして MIM技術の進歩と用途開発が進められてきました。一方で，アジア圈で は MIM 技術や製品についても沉用化が進み，欧米では新たな $3 \mathrm{D}$ 積層造形技術が実用段階に入っています。本特集では，複合 材料や磁性材料の射出成形，表面処理による MIM 製品の機能性向上，チタン合金の高疲労強度化に関する講演（協会賞受賞記 念講演）に加えて, MIMメーカーの技術と経験を活かした事業参入に期待が持てるバインダージェット技術に関する講演（特 別講演）が予定されています．多くの方々にご参加いただき，活発な議論が交わされ，産業の発展に寄与することを期待してお ります.

\section{4. ナノ材料の合成とその複合化技術の新展開}

セラミックス，金属，炭素などのナノ材料は，物質固有の性質に加え，ナノ領域のサイズに由来する機能を発現する可能性が あることから大きな注目を集めており，近年合成手法が発展してきました。また，2つの化学的に異なる面を有するヤヌスナノ 材料などの新しいナノ材料や，ナノ材料同士の複合化，高分子などをマトリクスとした複合化についても，報告が増加していま す. 本特集では，本協会の将来において重要な役割を果たしていくナノ材料の合成とその複合化，さらには得られる材料の応用 展開に関して様々な観点からの議論いたします. 多くの皆様にご参加いただき, 活発な議論の場となることを期待しております. 